Article

\title{
Copper(II) Binding by the Earliest Vertebrate Gonadotropin-Releasing Hormone, the Type II Isoform, Suggests an Ancient Role for the Metal
}

\author{
Lorraine Peacey, Charlotte Peacey, Adele Gutzinger and Christopher E. Jones * \\ School of Science, Western Sydney University, Locked bag 1797, Penrith 2751, Australia; \\ L.Peacey@westernsydney.edu.au (L.P.); charlotte.peacey@students.mq.edu.au (C.P.); \\ 19596769@student.westernsydney.edu.au (A.G.) \\ * Correspondence: c.jones@westernsydney.edu.au; Tel.: +61-2-9685-9908
}

Received: 27 September 2020; Accepted: 22 October 2020; Published: 24 October 2020

\begin{abstract}
In vertebrate reproductive biology copper can influence peptide and protein function both in the pituitary and in the gonads. In the pituitary, copper binds to the key reproductive peptides gonadotropin-releasing hormone I (GnRH-I) and neurokinin B, to modify their structure and function, and in the male gonads, copper plays a role in testosterone production, sperm morphology and, thus, fertility. In addition to GnRH-I, most vertebrates express a second isoform, GnRH-II. GnRH-II can promote testosterone release in some species and has other non-reproductive roles. The primary sequence of GnRH-II has remained largely invariant over millennia, and it is considered the ancestral GnRH peptide in vertebrates. In this work, we use a range of spectroscopic techniques to show that, like GnRH-I, GnRH-II can bind copper. Phylogenetic analysis shows that the proposed copper-binding ligands are retained in GnRH-II peptides from all vertebrates, suggesting that copper-binding is an ancient feature of $\mathrm{GnRH}$ peptides.
\end{abstract}

Keywords: copper; gonadotropin-releasing hormone; neuropeptide; peptide; fertility; reproduction

\section{Introduction}

The development of mammalian reproductive capability is dependent on successful functioning of the hypothalamic-pituitary-gonad (HPG) axis. A key peptide in the HPG axis is gonadotropin-releasing hormone I (GnRH-I), a hormone released from hypothalamic neurons into the portal circulation in the pituitary median eminence. GnRH-I travels to the anterior pituitary where it acts on gonadotrope cells to trigger the release of luteinizing hormone (LH) and follicle-stimulating hormone (FSH), which are responsible for the development of androgens in the gonads. Although GnRH-I is thought to act primarily at the gonadotrope cells, there is evidence for activity outside the pituitary, given, for example, the presence of GnRH-I receptor in the testes of many mammals [1]. GnRH-I is secreted in a pulsatile manner, and timing of the pulses is regulated by the peptides kisspeptin, dynorphin and neurokinin B [2]. Kisspeptin and neurokinin B lead to release of GnRH-I, whereas dynorphin inhibits release and therefore suppresses the GNRH-I pulse. In addition to GnRH-I, most vertebrates have a second isoform, GnRH-II, which is widely expressed in the central and peripheral nervous system, and in non-neuronal cells. This peptide is very highly conserved across all species and is thought to represent the earliest form of GnRH. The high conservation suggests that the role GnRH-II performs is critical, yet a distinct role for the peptide remains elusive and its function may differ in different species. In humans, a receptor for GnRH-II is not expressed, but the peptide can activate the GnRH-I receptor and trigger the release of LH and FSH from gonadotropes [3]. In primates, GnRH-II may have a role in regulating a pre-ovulatory LH surge [4]. In males, some species express a full-length GnRH-II receptor in the testes, and GnRH-II can trigger the release of testosterone that is independent of LH [5]. 
Many trace elements, including metals such as copper and zinc, have critical roles in reproductive pathways [6,7]. Copper has a long history in reproduction and has been implicated in normal physiological roles, as well as toxic processes. In the mid-1930s, Fevold et al. showed that administration of copper salts could induce ovulation in a female rabbit [8]. This effect was predominantly due to effects early in the HPG axis which trigger the enhanced release of LH [9]. The effect of copper on LH release may occur in several different ways: The metal may directly release LH by modulating the activity of GnRH receptors on gonadotropic cells [10,11]; by amplifying the GnRH-I releasing activity of prostaglandin E2 [12]; by binding to GnRH-I and enhancing or modifying its receptor-binding activity [13-15]; and/or by binding to neurokinin B, a peptide that indirectly modulates GnRH-I release $[16,17]$. The ability of copper to modify the structure and function of GnRH-I and neurokinin B and influence early events in the HPG axis has recently been reviewed [18]. Outside of the pituitary, copper can have effects directly at the gonads, and it is well documented that copper can play a role in spermatogenesis and in sperm motility [19]. Several proteins involved in copper homeostasis, including the import pump Ctr1, are expressed in germ cells and mature spermatozoa, highlighting the role copper plays in both development and then function of sperm cells [20-23]. When free, or not bound to proteins or other molecules, copper is well-known to participate in reactions that generate damaging reactive oxygen species. Indeed, high copper concentrations in the environment can have deleterious effects on sperm quality thought to be related to oxidative stress $[24,25]$.

GnRH-I or its homologues exist throughout the Bilateria, and analysis of the evolutionary origin of GnRH and related peptides has suggested that they evolved from a common ancestor [26,27]. Recently, a GnRH-type peptide derived from the echinoderm Asterias rubens was shown to bind copper, suggesting that copper-binding may be a feature of the earliest forms of GnRH [28]. Although the copper-binding ability of GnRH-I is relatively well established, the ability of other isoforms has not been studied. If GnRH-II represents the earliest form of GnRH peptides, then it could reasonably be expected to bind copper if this was indeed a genuine feature of the peptide family and one that has been retained in many extant species. Thus, the objective of this study was to explore and characterize the copper-binding ability of GnRH-II.

\section{Results and Discussion}

\subsection{GnRH-II Binds Copper with a 1:1 Stoichiometry in a Four-Nitrogen Environment}

We firstly assessed the binding of copper by GnRH-II, using mass spectroscopy. The electrospray mass spectrum of GnRH-II in the absence of $\mathrm{Cu}$ (II) (apo-GnRH-II) shows prominent peaks due to mono and doubly charged species at $m / z 1236.4[\mathrm{M}+\mathrm{H}]^{+}$(Figure 1a) and $m / z 618.7[\mathrm{M}+2 \mathrm{H}]^{2+}$ (not shown). An additional major peak at $m / z 1065.3$ can be attributed to in-source fragmentation of GnRH-II. The addition of an equimolar amount of $\mathrm{Cu}^{2+}$ to GnRH-II prior to ESI-MS leads to the spectrum shown in Figure 1a (upper spectrum). The spectrum has predominant peaks due to apo-GnRH-II, but there is a clear singly charged peak at $m / z 1297.33$ attributable to $\left[\left(\mathrm{M}+\mathrm{Cu}^{2+}-2 \mathrm{H}\right)+\mathrm{H}^{+}\right]^{+}$. At the $\mathrm{pH}$ ( $\mathrm{pH}$ 7.6) of this experiment, the loss of two protons is predicted to be due to copper coordination displacing two amide protons, as is observed in many copper-binding peptides and proteins, including GnRH-I [13,28]. The peak near $m / z 1333$ is a singly charged adduct of unknown composition. Simulation of the pattern of peaks at $m / z 1297.33$, assuming a $\mathrm{Cu}^{\mathrm{II}} \mathrm{GnRH}-\mathrm{II}$ complex shows very good agreement with the experimental pattern (Figure 1b, inset). No peaks due to multi-copper complexes with GnRH-II were observed, despite acquiring data to $3000 \mathrm{Da}$. The presence of a peak due to [C $\left.\mathrm{Cu}^{\mathrm{II}} \mathrm{GnRH}-\mathrm{II}\right]$ suggests a 1:1 stoichiometry, which is the most stable stoichiometry.

We next assessed the binding, using circular dichroism in the visible wavelength region. If copper binds to a protein or peptide via amide nitrogen atoms and displaces the protons as predicted by the ESI-MS data, then quite intense peaks are generally observed in the visible region of the CD spectrum [29]. The peaks arise due to coordination-induced chirality developed around the metal binding site [30]. The visible-CD spectra obtained from [Cu $\left.{ }^{\mathrm{II}} \mathrm{GnRH}-\mathrm{II}\right]$ are shown in Figure $1 \mathrm{~b}$ (solid 
line). The spectrum has a positive signal near $600 \mathrm{~nm}$ and a negative signal below $350 \mathrm{~nm}$ that correspond to copper $d$ - $d$ transitions and most likely an imidazole $\rightarrow \mathrm{Cu}$ (II) charge transfer transition, respectively [28,31]. Intriguingly, the position of the peaks in the $\mathrm{CD}$ spectrum of [C $\left.{ }^{\mathrm{II}} \mathrm{GnRH}-\mathrm{II}\right]$ is identical to that previously obtained from [Cu $\left.{ }^{\mathrm{II}} \mathrm{GnRH}-\mathrm{I}\right]$ (Figure 1b, dashed line) [32,33]. GnRH-I (pEHWSYGLRPG- $\mathrm{NH}_{2}$ ) is thought to coordinate $\mathrm{Cu}(\mathrm{II})$ via the $\mathrm{N}$-terminal groups, incorporating deprotonated amide nitrogen atoms of the pyroglutamyl ring and His2 and the imidazole nitrogen of His2 with a solvent oxygen contributing to generate a four-coordinate copper site [13]. The CD spectra suggest that GnRH-II (pEHWSHGWYPG-NH $\mathrm{N}_{2}$ ), which has the same $\mathrm{N}$-terminal sequence as GnRH-I, is coordinating $\mathrm{Cu}(\mathrm{II})$ in a similar manner.
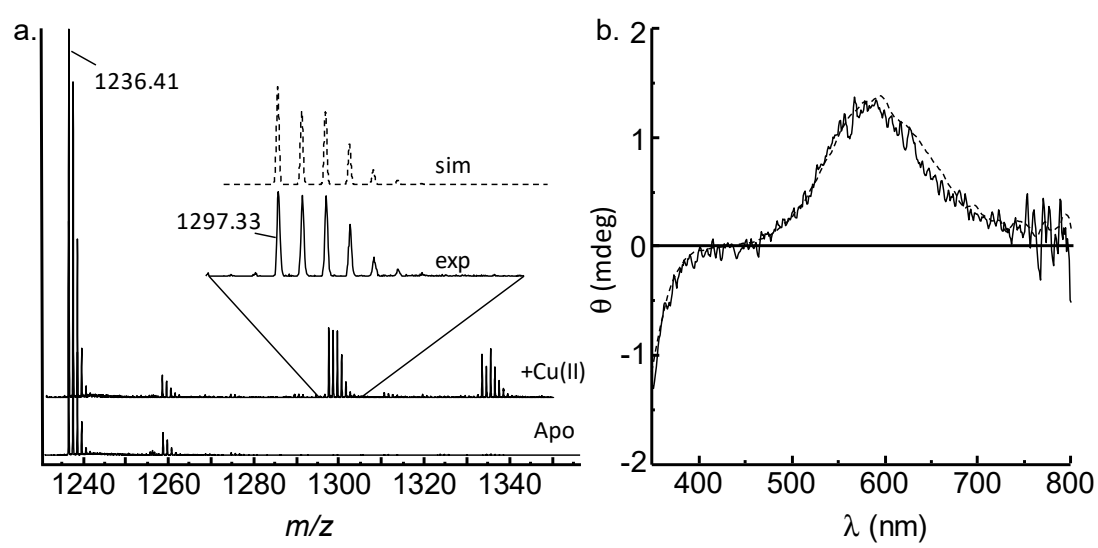

Figure 1. Mass spectrometry and visible-CD analysis of [Cu $\left.\mathrm{Cu}^{\mathrm{II}} \mathrm{GnRH}-\mathrm{II}\right]$. (a) The mass spectrum obtained after the addition of one equivalent $\mathrm{Cu}(\mathrm{II})$ to apo-GnRH-II $(100 \mu \mathrm{M})$ results in peaks around $\mathrm{m} / \mathrm{z} 1297$ that are not present in the spectrum of apo-GnRH-II. The mass and isotope distribution can be well simulated, assuming that GnRH-II loses two protons to form a mono-nuclear copper complex (inset). The peaks near $\mathrm{m} / \mathrm{z} 1335$ are an unidentified adduct of the copper complex, and the peaks at $\mathrm{m} / \mathrm{z} 1236.41$ are apo-GnRH-II. (b) The visible-CD spectrum of [Cu $\left.{ }^{\mathrm{II}} \mathrm{GnRH}-\mathrm{II}\right](50 \mu \mathrm{M})$ has a positive signal near $600 \mathrm{~nm}$ and a negative signal near $350 \mathrm{~nm}$ (solid line). The spectrum is identical to the visible-CD spectrum of [Cu $\left.{ }^{\mathrm{II}} \mathrm{GnRH}-\mathrm{I}\right]$ (dashed line).

ESI-MS and CD data suggested that amide nitrogen atoms were involved in coordinating copper, so we next used EPR spectroscopy to further investigate if nitrogen coordination was occurring. The experimental spectra derived from frozen solutions of GnRH-II in the presence of 0.2 and 0.8 equivalents of $\mathrm{Cu}$ (II) are shown in Figure 2a. The spectra are typical of axial-type copper complexes $\left(g_{x}, g_{y}<g_{z}\right)$. The spectrum obtained from GnRH-II in the presence of 0.8 equivalents $\mathrm{Cu}$ (II) can be well simulated (Figure 2a, $0.8 \mathrm{Cu} \mathrm{sim}$ ) with the parameters given in Table 1. The copper hyperfine parameters at $g_{z}$ were mapped to the Peisach and Blumberg plots, to establish that the copper ion in [Cu $\left.{ }^{\mathrm{II}} \mathrm{GnRH}-\mathrm{II}\right]$ is most likely coordinated in an environment that contains predominantly $4 \mathrm{~N}$ or 3N1O ligands [34]. These data are consistent with the ESI-MS and CD data. However, the hyperfine splitting at $\mathrm{g}_{\mathrm{z}}$ for GnRH-II $\left(196.8 \times 10^{-4} \mathrm{~cm}^{-1}\right)$ is larger than that observed for GnRH-I $(176.7 \times$ $10^{-4} \mathrm{~cm}^{-1}$ ), suggesting that the copper-GnRH-II complex contains more nitrogen donor atoms than the copper-GnRH-I complex [33]. With nitrogen ligands there is often superhyperfine coupling observable at both $g_{z}$ and $g_{x, y}$ that, in many cases, can be used to estimate the number of nitrogen donor atoms $[17,35,36]$. However, in the case of $\left[\mathrm{Cu}^{\mathrm{II}} \mathrm{GnRH}-\mathrm{II}\right]$, superhyperfine coupling is not readily apparent, and differentiation of the spectra did not reveal additional detail, most likely due to broadening phenomena [35]. It is possible that multiple species (e.g., $4 \mathrm{~N}$ and $3 \mathrm{~N} 1 \mathrm{O}$ species) contribute to the broadening. Analysis of the visible electronic spectrum of $\left[\mathrm{Cu}^{\mathrm{II}} \mathrm{GnRH}-\mathrm{II}\right]$ (Figure $2 \mathrm{~b}$ ) shows a $\lambda_{\max }$ at $520 \mathrm{~nm}$ at $\mathrm{pH}$ 8. Peaks at this wavelength are consistent with copper in a four-nitrogen site [28]. However, there is a shoulder apparent at $\sim 600 \mathrm{~nm}$, suggesting there is some copper with weaker-field donor atoms than nitrogen, most likely the inclusion of oxygen donor atoms. Indeed, 
GnRH-I binds copper in a site that incorporates an oxygen ligand, and the $\lambda_{\max }$ is near $600 \mathrm{~nm}$ [33]. The majority of copper is in a four-nitrogen site in GnRH-II, and there is likely a proportion that is a three-nitrogen site; however, the stoichiometry is still 1:1. In line with the EPR data, the $\lambda_{\max }$ at $520 \mathrm{~nm}$ for [ $\left.\mathrm{Cu}^{\mathrm{II}} \mathrm{GnRH}-\mathrm{II}\right]$ is consistent with GnRH-II having more nitrogen atoms coordinating copper than does GnRH-I. The binding is at $\mathrm{pH} \mathrm{8,} \mathrm{but} \mathrm{a} \mathrm{lack} \mathrm{of} \mathrm{coordination} \mathrm{at} \mathrm{pH} 3$ is consistent with the nitrogen donors being from an amide or the imidazole nitrogen atoms from histidine amino acids, which become available at $\mathrm{pH}$ values greater than the $\mathrm{pKa}$ of the imidazole group. GnRH-II contains histidine amino acids at positions 2 and 5, and the imidazole nitrogen of His5 is the mostly likely source of the additional nitrogen required to generate a $4 \mathrm{~N}$ site in GnRH-II. The $4 \mathrm{~N}$ environment suggested by the EPR and electronic spectra may seem incongruent with the CD data, which suggest that GnRH-II has an identical 3N1O site to that in GnRH-I (Figure 1b). However, at visible wavelengths, the $\mathrm{CD}$ spectra of copper peptide complexes are dominated by the vicinal effect arising from main chain (amide) coordination and the subsequent location of the chiral $\alpha$-carbon [30]. Copper sites that incorporate only coordination by atoms from amino acid side chains have negligible visible $C D$ spectra [37,38]. In [Cu $\left.{ }^{\mathrm{II}} \mathrm{GnRH}-\mathrm{II}\right]$, the inclusion of a nitrogen from only the His5 imidazole group would not contribute to the chirality of the copper site and would be unlikely to alter the position of the main chain groups responsible for the $C D$ signal and thus the $C D$ spectrum retains features consistent with the site found in [Cu $\left.{ }^{\mathrm{II}} \mathrm{GnRH}-\mathrm{I}\right]$. However, the inclusion of a fourth nitrogen will affect the $\lambda_{\max }$ observed in the electronic spectrum (Figure 2b), due to the difference in ligand field strength, as compared to oxygen.
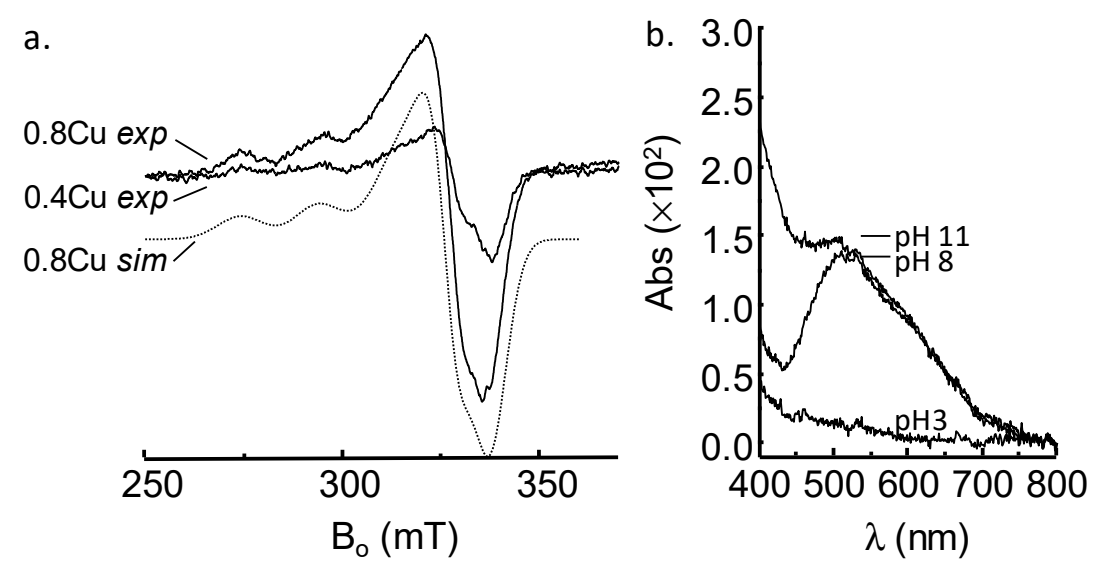

Figure 2. (a) X-band EPR spectra of GnRH-II $(50 \mu \mathrm{M})$ in the presence of 0.4 and 0.8 equivalents of $\mathrm{Cu}$ (II). The dotted line, $0.8 \mathrm{Cu} \operatorname{sim}$, is the simulation of the $0.8 \mathrm{Cu} \mathrm{GnRH}-\mathrm{II}$ experimental spectrum generated by using the parameters in Table 1. (b) Electronic spectra of GnRH-II $(100 \mu \mathrm{M})$ at pH 3, pH 8 and $\mathrm{pH}$ 11. Maximal binding occurs at $\mathrm{pH} 8$, and the maximal absorption wavelength is observed at $\sim 520 \mathrm{~nm}$. A shoulder is apparent near $600 \mathrm{~nm}$ in both the $\mathrm{pH} 8$ and pH 11 spectra.

Table 1. Simulation parameters for the EPR spectrum of [Cu $\left.{ }^{\mathrm{II}} \mathrm{G} n \mathrm{RH}-\mathrm{II}\right]$.

\begin{tabular}{cc}
\hline Parameter & Value \\
\hline$g_{i}(i=\mathrm{x}, \mathrm{y}, \mathrm{z})$ & $2.067,2.067,2.222$ \\
$A_{i}\left({ }^{3} \mathrm{Cu}\right)\left(\times 10^{-4} \mathrm{~cm}^{-1}\right)$ & $10.0,10.0,196.8$ \\
Linewidth $\left(\times 10^{-4} \mathrm{~cm}^{-1}\right)$ & 4.67 \\
$g$-strain & $0.052,0.058,0.086$ \\
$A$-strain & $\left(\times 10^{-4} \mathrm{~cm}^{-1}\right)$ \\
\hline
\end{tabular}

GnRH-II contains two tryptophan amino acids, at position 3 and 7, so we next used fluorescence spectroscopy to monitor $\mathrm{Cu}$ (II)-peptide binding. Excitation of apo-GnRH-II ( $50 \mathrm{nM}$ ) leads to maximal emission at $\sim 340 \mathrm{~nm}$ (Figure 3a) consistent with solvent exposed tryptophan residues in a natively unstructured peptide. Titrating $\mathrm{Cu}(\mathrm{II})$ into the $\mathrm{GnRH}-\mathrm{II}$ solution causes a reduction in the emission 
intensity, presumably due to copper-peptide interactions. At one equivalent of $\mathrm{Cu}(\mathrm{II})$, the emission has been quenched $\sim 50 \%$, and the addition of more $\mathrm{Cu}$ (II) to two equivalents causes only a further $20 \%$ quenching. In line with the MS data, this tends to suggest a stoichiometry of 1:1. Notably, the emission is not completely quenched, and we speculate that one of the two tryptophans is more affected by copper coordination than the other. We predict Trp3, adjacent to His2, a potential copper ligand, is predominantly quenched by copper coordination, whereas $\operatorname{Trp} 7$, more remote from the $\mathrm{Cu}$ (II) site, is likely to be less effected.
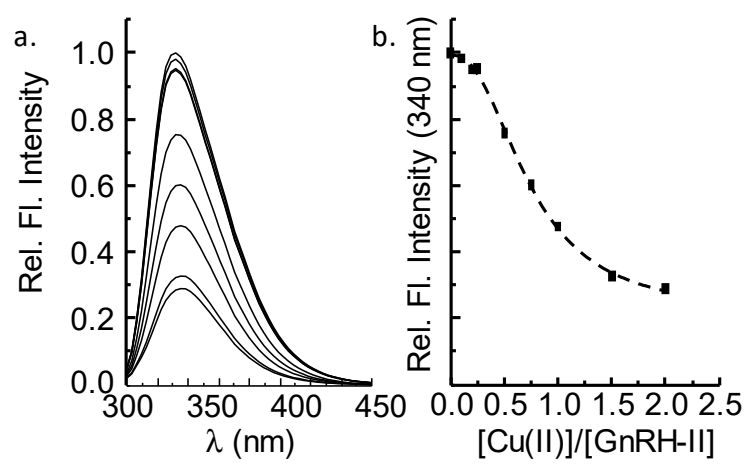

Figure 3. Fluorescence spectroscopy of GnRH-II. (a) Emission spectra of tryptophan (excitation $280 \mathrm{~nm}$ ) amino acids in GnRH-II (50 nM) as a function of added $\mathrm{Cu}(\mathrm{II})$. (b) Emission at $340 \mathrm{~nm}$ plotted as a function of copper equivalents ([Cu(II)]/[GnRH-II]). The emission intensity has been reduced by $\sim 50 \%$ after the addition of one equivalent $\mathrm{Cu}(\mathrm{II})$, and there is little change in intensity after 1.5 equivalents.

Taken together, the spectroscopic data show that GnRH-II can bind $\mathrm{Cu}(\mathrm{II})$ to form a 1:1 complex, and the EPR data and electronic spectroscopy suggest that the copper ion is in a four-nitrogen environment. GnRH-I (pEHWSYGLRPG-NH $\mathrm{N}_{2}$ ) binds copper in an $N$-terminal 3N1O environment that incorporates two amide nitrogens and an imidazole nitrogen (i.e., $\left\{2 \mathrm{~N}_{\mathrm{a}}, \mathrm{N}_{\mathrm{im}}, \mathrm{O}\right\}$ ), and GnRH-II (pEHWSHGWYPG-NH $\mathrm{N}_{2}$ ) contains the same $\mathrm{N}$-terminal sequence and only differs from GnRH-I by three amino acids $[13,33]$. Notably, GnRH-II includes a second histidine at position 5, and the spectroscopic data are consistent with GnRH-II binding copper via the $N$-terminal pEHxxH sequence in a coordination sphere that includes two amide and two imidazole nitrogens (i.e., $\left\{2 \mathrm{~N}_{\mathrm{a}}\right.$, $\left.2 \mathrm{~N}_{\mathrm{im}}\right\}$ ) to generate the four-nitrogen environment (Figure 4). The inclusion of a 'remote' imidazole ligand is not uncommon, and, indeed, the proposed [Cu $\left.{ }^{\mathrm{II}} \mathrm{GnRH}-\mathrm{II}\right]$ site has some similarity to the copper site in a peptide fragment of human angiogenin [31].

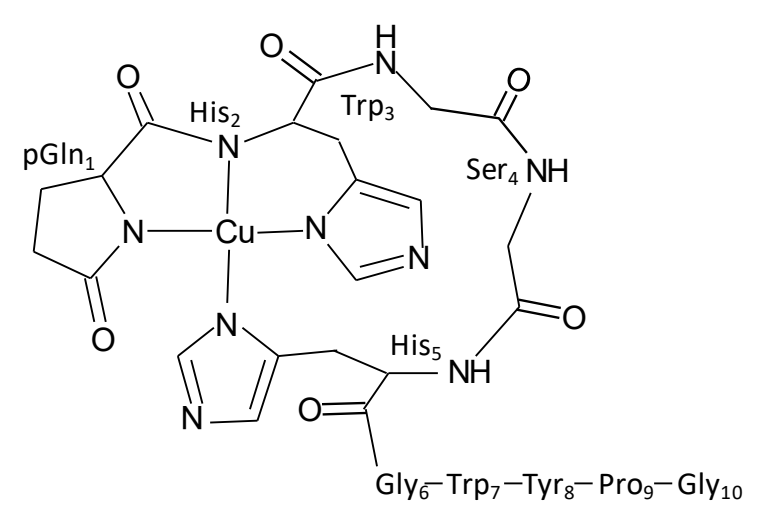

Figure 4. Proposed structure of the copper(II) complex of GnRH-II at pH 7.6. The side chains of Trp3 and Ser4 are omitted for clarity. 


\subsection{Histidine Amino-Acids Are Highly Conserved in Vertebrate GnRH-II}

The sea lamprey Petromyzon marinus is considered a basal vertebrate, having remained unchanged for millennia. Lamprey GnRH-II contains the pEHxxH sequence containing the proposed copper ligands, suggesting that the ability to coordinate copper was a feature of the earliest vertebrate peptide. The primary sequence of GnRH-II has remained largely invariant for several million years of vertebrate development, suggesting strong selective pressure to retain the sequence (Figure 5) [27,39-41]. The retention of the copper ligands suggests the metal may influence GnRH-II structure and function in all vertebrate species. The invertebrate chordates tend to not contain a peptide with a $\mathrm{pEHxxH}$ sequence despite expressing several GnRH-I isoforms [27,42]. However, the tunicate Chelyosoma productum has a peptide identified as a tGnRH-II that contains a $\mathrm{pEHxxxxH}$ sequence (Figure 5) [43]. Although the presence of this sequence implies the peptide may bind metal with some similarity to vertebrate GnRH-II, we predict it is unlikely given tGNRH-II forms a disulfide-linked homodimer that would sterically hinder His7 from participating in metal coordination [43,44].

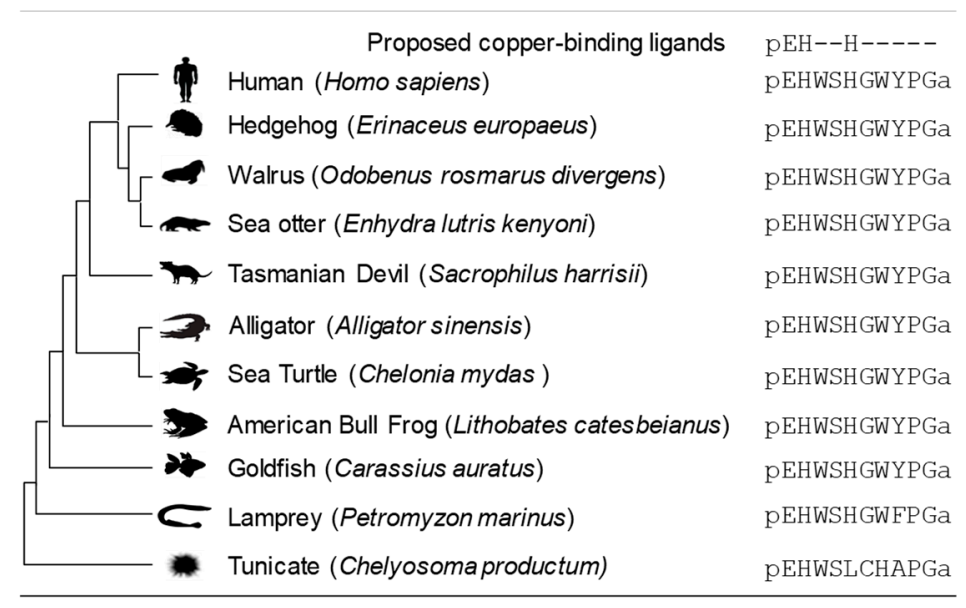

Figure 5. Diagram showing GnRH-II sequences from deuterostomes. All vertebrate GnRH-II peptides contain the $\mathrm{pEHxxH}$ sequence proposed to be the copper binding site. The site is invariant in vertebrates and is not observed in deuterostome invertebrates, such as the tunicates. The peptides are all amidated at the $C$-terminus, denoted by an 'a' in the primary sequence.

\section{Materials and Methods}

\subsection{Materials}

Mammalian gonadotropin-releasing hormone II (GnRH-II, pEHWSHGWYPG- $\mathrm{NH}_{2}$ ) was synthesized by Synpeptide (Shanghai, China), at $>95 \%$ purity, and was not purified further. The concentration of this peptide was determined by using the extinction coefficient of tryptophan $\left(5690 \mathrm{M}^{-1} \mathrm{~cm}^{-1}\right)$ and tyrosine $\left(1290 \mathrm{M}^{-1} \mathrm{~cm}^{-1}\right)$ at $280 \mathrm{~nm}$. A stock solution of $\mathrm{CuCl}_{2} \cdot \mathrm{H}_{2} \mathrm{O}$ was prepared in Milli-Q water (18 M $\Omega$, MerckMillipore, Victoria, Australia) that was metal-free, as determined by electron paramagnetic resonance. Working solutions of $\mathrm{CuCl}_{2} \cdot \mathrm{H}_{2} \mathrm{O}$ were prepared from the stock solution on the day of use. The buffer was $20 \mathrm{mM}$ 4-ethylmorpholine (Sigma-Aldrich, Castle Hill, Australia), $\mathrm{pH} 7.6$ unless otherwise indicated. This buffer does not coordinate copper.

\subsection{Mass Spectroscopy (MS)}

Mass spectroscopic data were acquired on a XEVO-QToF instrument controlled by MassLynx software (Waters Corp., Milford, MA, USA). Spectra were collected in positive ion mode, the capillary voltage was $3.5 \mathrm{~V}$, the cone voltage was $30 \mathrm{~V}$, the source temperature was $80^{\circ} \mathrm{C}$ and the mass range was 200-3000 Da. Peptide samples were diluted, using a 1:1 acetonitrile:water solution containing $0.1 \%$ 
formic acid. The samples were applied to the interface by direct infusion, at a flow rate of ca. $10 \mu \mathrm{L} / \mathrm{min}$. Masses were calibrated to leucine enkephlin $\mathrm{m} / \mathrm{z}$ 556.28. Spectra were simulated by using IsoPro3.

\subsection{Electronic Spectroscopy}

UV/Visible spectra were acquired on a Cary 100 spectrometer operated with WinUV software (Agilent Technologies Australia, Victoria, Australia). All spectra were collected by using a $1.0 \mathrm{~cm}$ pathlength cuvette over a wavelength range of $200-800 \mathrm{~nm}$. The scan rate was $300 \mathrm{~nm} / \mathrm{min}$.

\subsection{Fluorescence Spectroscopy}

Fluorescence spectra were acquired using an FS5 fluorimeter (Edinburgh Instruments Ltd., Livingston, Scotland, UK). A $1.0 \mathrm{~cm} \times 1.0 \mathrm{~cm}$ far-UV quartz cuvette (Spectrocell, Oreland, PA, USA) was used for all measurements. Tryptophan emission was collected over the range $300 \mathrm{~nm}-450 \mathrm{~nm}$ after excitation at $280 \mathrm{~nm}\left(5 \mathrm{~nm}\right.$ slit width). Spectra were collected at room temperature $\left(\sim 25^{\circ} \mathrm{C}\right)$.

\subsection{Electron Paramagnetic Resonance (EPR)}

X-band ( 9.4 GHz) EPR spectra were collected on a Bruker EMXplus spectrometer equipped with an EMX PremiumX bridge (Bruker BioSpin, Victoria, Australia). The temperature was held at $150 \pm 5 \mathrm{~K}$, using nitrogen vapor regulated by a ER4131 variable temperature controller. The power was $0.63 \mathrm{~mW}$, the modulation frequency was $100 \mathrm{kHz}$ and the modulation amplitude was $5.0 \mathrm{G}$. Twenty scans were acquired and averaged for each sample, and a baseline (buffer-only) spectrum was subtracted from each sample spectrum. Simulation of the EPR spectra was performed by using Easyspin running in MatLab 2020a [45]. Simulations used matrix diagonalization to determine the copper hyperfine and Zeeman parameters, and linewidths were fitted by using a correlated distribution of $g$ - and $A$-strains [46].

\subsection{Circular Dichroism (CD) Spectroscopy}

$\mathrm{CD}$ spectra were acquired on a Jasco J810 spectrometer at room temperature $\left(\sim 23^{\circ} \mathrm{C}\right)$ (Jasco, Easton, MD, USA). Spectra were collected from 300 to $800 \mathrm{~nm}$, data were acquired every $2 \mathrm{~nm}$ and at least 10 scans were averaged. A $1.0 \mathrm{~cm}$ pathlength cuvette was used.

\subsection{Phylogenetic Analysis}

The human GnRH-II sequence was used as a search sequence for BLAST analysis in Uniprot. A selection of vertebrate and invertebrates were chosen for comparison. Peptide sequences were also obtained from the published literature [26]. MEGAX (Molecular Evolutionary Genetics Analysis across computing platforms) and ClustalW were used to align sequences [47].

\section{Conclusions}

GnRH-II is widely distributed in the central and peripheral nervous system and in non-nervous tissues, including reproductive tissue. The primary sequence has remained unchanged for 500 million years, suggesting that the peptide has a role important enough to drive evolutionary pressure to retain the sequence; however, that function remains unclear. The work described here shows that GnRH-II binds copper in a site predicted to include amide nitrogen and histidine imidazole nitrogen donor atoms derived from the $\mathrm{pEHxxH} \mathrm{N-terminal} \mathrm{sequence.} \mathrm{GnRH-I} \mathrm{binds} \mathrm{copper} \mathrm{via} \mathrm{the} \mathrm{pEH}$ sequence (i.e., $\left\{2 \mathrm{~N}^{-}, \mathrm{N}_{\mathrm{im}}\right\}$ ) with a solvent derived oxygen as the fourth donor atom [13]. The data presented here predict that GnRH-II binds similarly to GnRH-I, but instead of a solvent oxygen, the imidazole of His5 is the fourth ligand. The binding of the His5 side chain will require movement of the backbone of GnRH-II, to generate the four-coordinate geometry (Figure 4). We speculate that the copper-induced structuring of GnRH-II will modify how the peptide interacts with a receptor, possibly the GnRH-I receptor in humans. The binding of copper may also allow GnRH-II to interact with a different receptor, consequently leading to functional diversity, depending on copper availability 
in the tissues where GnRH-II is expressed. Further work investigating the physiological consequences of copper-coordination remains to be explored. The binding of copper by GnRH-II and GnRH-I suggests that metal coordination has been a feature present in the earliest form of the peptide and has been retained during gene-duplication events that gave rise to other $\mathrm{GnRH}$ isoforms [41]. The reasons for the pressure to retain copper-binding ability in all deuterostome GnRH isoforms are unknown, but the work described here opens bioinorganic avenues of investigation that may lead to a greater understanding of GnRH-II function in vertebrate biology.

Author Contributions: Conceptualization, C.E.J. and L.P.; methodology, C.E.J., L.P. and C.P.; spectrometry, L.P. and C.E.J; sequence analysis, L.P. and C.P.; writing-drafting, review and editing, C.E.J., A.G., L.P. and C.P.; supervision, C.E.J. All authors have read and agreed to the published version of the manuscript.

Funding: This research was supported by intramural funding via a WSU Researcher Development ACA/DAP Grant (C.E.J.).

Acknowledgments: The Advanced Materials Characterization Facility (Western Sydney University) is thanked for access and assistance with Mass Spectrometry. Donald Thomas and the Mark Wainwright Analytical Centre (UNSW) are thanked for assistance with EPR spectrometry. We thank Maurice Elphick (Queen Mary, University of London) for helpful advice.

Conflicts of Interest: The authors declare no conflict of interest.

\section{References}

1. Sharpe, R.M.; Fraser, H.M. HCG stimulation of testicular LHRH-like activity. Nature 1980, 287, 642-643. [CrossRef]

2. Moore, A.M.; Coolen, L.M.; Porter, D.T.; Goodman, R.L.; Lehman, M.N. KNDy Cells Revisited. Endocrinology 2018, 159, 3219-3234. [CrossRef] [PubMed]

3. Neill, J.D.; Musgrove, L.C.; Duck, L.W. Newly recognized GnRH receptors: Function and relative role. Trends Endocrinol. Metab. 2004, 15, 383-392. [CrossRef] [PubMed]

4. Urbanski, H.F. Differential roles of GnRH-I and GnRH-II neurons in the control of the primate reproductive axis. Front. Endocrinol. (Lausanne) 2012, 3, 20. [CrossRef] [PubMed]

5. Desaulniers, A.T.; Cederberg, R.A.; Mills, G.A.; Ford, J.J.; Lents, C.A.; White, B.R. LH-Independent Testosterone Secretion Is Mediated by the Interaction Between GNRH2 and Its Receptor Within Porcine Testes. Biol. Reprod. 2015, 93, 45. [CrossRef]

6. Zhao, J.; Dong, X.; Hu, X.; Long, Z.; Wang, L.; Liu, Q.; Sun, B.; Wang, Q.; Wu, Q.; Li, L. Zinc levels in seminal plasma and their correlation with male infertility: A systematic review and meta-analysis. Sci. Rep. 2016, 6, 22386. [CrossRef]

7. Duncan, F.E.; Que, E.L.; Zhang, N.; Feinberg, E.C.; O'Halloran, T.V.; Woodruff, T.K. The zinc spark is an inorganic signature of human egg activation. Sci. Rep. 2016, 6, 24737. [CrossRef]

8. Fevold, H.L.; Hisaw, F.L.; Greep, R. Augmentation of the gonad stimulating action of pituitary extracts by inorganic substances, particularly copper salts. Am. J. Physiol. 1936, 117, 68-74. [CrossRef]

9. Suzuki, M.; Hiroi, M.; Sugita, S. Ovulation in rabbits following intravenous and intracerebral administration of copper sulphate. Acta Endocrinol. (Copenh) 1965, 50, 512-516. [CrossRef]

10. Hazum, E. Copper and thiol regulation of gonadotropin releasing hormone binding and luteinizing hormone release. Biochem. Biophys. Res. Commun. 1983, 112, 306-312. [CrossRef]

11. Schvartz, I.; Hazum, E. Copper induces luteinizing hormone release and desensitization of pituitary gonadotropes. Biochem. Biophys. Res. Commun. 1986, 136, 417-425. [CrossRef]

12. Barnea, A.; Colombani-Vidal, M.; Cho, G.; Hartter, D.E. Evidence for synergism between copper and prostaglandin $\mathrm{E} 2$ in stimulating the release of gonadotropin-releasing hormone from median eminence explants: Na+/Cl- requirements. Mol. Cell. Endocrinol. 1988, 56, 11-19. [CrossRef]

13. Nakamura, K.; Kodaka, M.; El-Mehasseb, I.M.; Gajewska, A.; Okuno, H.; Ochwanowska, E.; Witek, B.; Kozlowski, H.; Kochman, K. Further structural analysis of GnRH complexes with metal ions. Neuro Endocrinol. Lett. 2005, 26, 247-252. [PubMed]

14. Gajewska, A.; Zielinska-Gorska, M.; Wolinska-Witort, E.; Siawrys, G.; Baran, M.; Kotarba, G.; Biernacka, K. Intracellular mechanisms involved in copper-gonadotropin-releasing hormone ( $\mathrm{Cu}-\mathrm{GnRH})$ complex-induced 
cAMP/PKA signaling in female rat anterior pituitary cells in vitro. Brain Res. Bull. 2016, 120, 75-82. [CrossRef] [PubMed]

15. Herman, A.; Kozlowski, H.; Czauderna, M.; Kochman, K.; Kulon, K.; Gajewska, A. Gonadoliberin (GnRH) and its copper complex (Cu-GnRH) enzymatic degradation in hypothalamic and pituitary tissue in vitro. $J$. Physiol. Pharmacol. 2012, 63, 69-75.

16. Russino, D.; McDonald, E.; Hejazi, L.; Hanson, G.R.; Jones, C.E. The tachykinin peptide neurokinin B binds copper forming an unusual $\left[\mathrm{Cu}^{\mathrm{II}}(\mathrm{NKB})_{2}\right]$ complex and inhibits copper uptake into $1321 \mathrm{~N} 1$ astrocytoma cells. ACS Chem. Neurosci. 2013, 4, 1371-1381. [CrossRef] [PubMed]

17. Jayawardena, B.M.; Jones, M.R.; Hong, Y.; Jones, C.E. Copper ions trigger disassembly of neurokinin B functional amyloid and inhibit de novo assembly. J. Struct. Biol. 2019, 208, 107394. [CrossRef] [PubMed]

18. Peacey, L.; Elphick, M.R.; Jones, C.E. Roles of copper in neurokinin B and gonadotropin-releasing hormone structure and function and the endocrinology of reproduction. Gen. Comp. Endocrinol. 2020, 287, 113342. [CrossRef]

19. Roy, D.; Dey, S.; Majumder, G.C.; Bhattacharyya, D. Copper: A biphasic regulator of caprine sperm forward progression. Syst. Biol. Reprod. Med. 2014, 60, 52-57. [CrossRef]

20. Kuo, Y.M.; Gybina, A.A.; Pyatskowit, J.W.; Gitschier, J.; Prohaska, J.R. Copper transport protein (Ctr1) levels in mice are tissue specific and dependent on copper status. J. Nutr. 2006, 136, 21-26. [CrossRef]

21. Ogorek, M.; Lenartowicz, M.; Starzynski, R.; Jonczy, A.; Staron, R.; Doniec, A.; Krzeptowski, W.; Bednarz, A.; Pierzchala, O.; Lipinski, P.; et al. Atp7a and Atp7b regulate copper homeostasis in developing male germ cells in mice. Metallomics 2017, 9, 1288-1303. [CrossRef] [PubMed]

22. Steiger, D.; Fetchko, M.; Vardanyan, A.; Atanesyan, L.; Steiner, K.; Turski, M.L.; Thiele, D.J.; Georgiev, O.; Schaffner, W. The Drosophila copper transporter Ctr1C functions in male fertility. J. Biol. Chem. 2010, 285, 17089-17097. [CrossRef] [PubMed]

23. Kowal, M.; Lenartowicz, M.; Pecio, A.; Golas, A.; Blaszkiewicz, T.; Styrna, J. Copper metabolism disorders affect testes structure and gamete quality in male mice. Syst. Biol. Reprod. Med. 2010, 56, 431-444. [CrossRef]

24. Lettieri, G.; D’Agostino, G.; Mele, E.; Cardito, C.; Esposito, R.; Cimmino, A.; Giarra, A.; Trifuoggi, M.; Raimondo, S.; Notari, T.; et al. Discovery of the Involvement in DNA Oxidative Damage of Human Sperm Nuclear Basic Proteins of Healthy Young Men Living in Polluted Areas. Int. J. Mol. Sci. 2020, 21. [CrossRef] [PubMed]

25. Abdul-Rasheed, O.F. Association between seminal plasma copper and magnesium levels with oxidative stress in iraqi infertile men. Oman Med. J. 2010, 25, 168-172. [CrossRef] [PubMed]

26. Zandawala, M.; Tian, S.; Elphick, M.R. The evolution and nomenclature of GnRH-type and corazonin-type neuropeptide signaling systems. Gen. Comp. Endocrinol. 2018, 264, 64-77. [CrossRef]

27. Roch, G.J.; Busby, E.R.; Sherwood, N.M. GnRH receptors and peptides: Skating backward. Gen. Comp. Endocrinol. 2014, 209, 118-134. [CrossRef]

28. Tran, K.K.; Jayawardena, B.M.; Elphick, M.R.; Jones, C.E. A gonadotropin-releasing hormone type neuropeptide with a high affinity binding site for copper(ii) and nickel(ii). Metallomics 2019, 11, 404-414. [CrossRef]

29. Tsangaris, J.M.; Martin, R.B. Visible circular dichroism of copper(II) complexes of amino acids and peptides. J. Am. Chem. Soc. 1970, 92, 4255-4260. [CrossRef]

30. Stanyon, H.F.; Cong, X.; Chen, Y.; Shahidullah, N.; Rossetti, G.; Dreyer, J.; Papamokos, G.; Carloni, P.; Viles, J.H. Developing predictive rules for coordination geometry from visible circular dichroism of copper(II) and nickel(II) ions in histidine and amide main-chain complexes. FEBS J. 2014, 281, 3945-3954. [CrossRef]

31. La Mendola, D.; Farkas, D.; Bellia, F.; Magri, A.; Travaglia, A.; Hansson, O.; Rizzarelli, E. Probing the copper(II) binding features of angiogenin. Similarities and differences between a N-terminus peptide fragment and the recombinant human protein. Inorg. Chem. 2012, 51, 128-141. [CrossRef] [PubMed]

32. Gerega, K.; Kozlowski, H.; Masiukiewicz, E.; Pettit, L.D.; Pyburn, S.; Rzeszotarska, B. Metal complexes of luteinizing hormone-releasing hormone (LHRH). potentiometric and spectroscopic studies. J. Inorg. Biochem. 1988, 33, 11-18. [CrossRef]

33. Gul, A.S.; Tran, K.K.; Jones, C.E. Neurokinin B and serum albumin limit copper binding to mammalian gonadotropin releasing hormone. Biochem. Biophys. Res. Commun. 2018, 497, 1-6. [CrossRef] [PubMed] 
34. Peisach, J.; Blumberg, W.E. Structural implications derived from the analysis of electron paramagnetic resonance spectra of natural and artificial copper proteins. Arch. Biochem. Biophys. 1974, 165, 691-708. [CrossRef]

35. Bennett, B.; Kowalski, J.M. EPR Methods for Biological Cu(II): L-Band CW and NARS. Methods Enzymol. 2015, 563, 341-361. [CrossRef]

36. Hyde, J.S.; Bennett, B.; Walter, E.D.; Millhauser, G.L.; Sidabras, J.W.; Antholine, W.E. EPR of Cu ${ }^{2+}$ prion $^{2}$ protein constructs at $2 \mathrm{GHz}$ using the g(perpendicular) region to characterize nitrogen ligation. Biophys. J. 2009, 96, 3354-3362. [CrossRef]

37. Syme, C.D.; Nadal, R.C.; Rigby, S.E.; Viles, J.H. Copper binding to the amyloid-beta (Abeta) peptide associated with Alzheimer's disease: Folding, coordination geometry, $\mathrm{pH}$ dependence, stoichiometry, and affinity of Abeta-(1-28): Insights from a range of complementary spectroscopic techniques. J. Biol. Chem. 2004, 279, 18169-18177. [CrossRef]

38. Jancso, A.; Paksi, Z.; Jakab, N.; Gyurcsik, B.; Rockenbauer, A.; Gajda, T. Solution chemical properties and catecholase-like activity of the copper(II)-Ac-His-His-Gly-His-OH system, a relevant functional model for copper containing oxidases. Dalton Trans. 2005, 3187-3194. [CrossRef]

39. Millar, R.P. GnRHs and GnRH receptors. Anim. Reprod. Sci. 2005, 88, 5-28. [CrossRef]

40. Sherwood, N.M.; Lovejoy, D.A.; Coe, I.R. Origin of mammalian gonadotropin-releasing hormones. Endocr. Rev. 1993, 14, 241-254. [CrossRef]

41. Kavanaugh, S.I.; Nozaki, M.; Sower, S.A. Origins of gonadotropin-releasing hormone (GnRH) in vertebrates: Identification of a novel GnRH in a basal vertebrate, the sea lamprey. Endocrinology 2008, 149, 3860-3869. [CrossRef] [PubMed]

42. Adams, B.A.; Tello, J.A.; Erchegyi, J.; Warby, C.; Hong, D.J.; Akinsanya, K.O.; Mackie, G.O.; Vale, W.; Rivier, J.E.; Sherwood, N.M. Six novel gonadotropin-releasing hormones are encoded as triplets on each of two genes in the protochordate, Ciona intestinalis. Endocrinology 2003, 144, 1907-1919. [CrossRef] [PubMed]

43. Powell, J.F.; Reska-Skinner, S.M.; Prakash, M.O.; Fischer, W.H.; Park, M.; Rivier, J.E.; Craig, A.G.; Mackie, G.O.; Sherwood, N.M. Two new forms of gonadotropin-releasing hormone in a protochordate and the evolutionary implications. Proc. Natl. Acad. Sci. USA 1996, 93, 10461-10464. [CrossRef] [PubMed]

44. Terakado, K. Induction of gamete release by gonadotropin-releasing hormone in a protochordate, Ciona intestinalis. Gen. Comp. Endocrinol. 2001, 124, 277-284. [CrossRef]

45. Stoll, S.; Schweiger, A. EasySpin, a comprehensive software package for spectral simulation and analysis in EPR. J. Magn. Reson. 2006, 178, 42-55. [CrossRef]

46. Froncisz, W.; Hyde, J.S. Broadening of strains of lines in the G-parallel region of $\mathrm{Cu}^{2+}$ electron-paramagnetic resonance spectra. J. Chem. Phys. 1980, 73, 3123-3131. [CrossRef]

47. Kumar, S.; Stecher, G.; Li, M.; Knyaz, C.; Tamura, K. MEGA X: Molecular Evolutionary Genetics Analysis across Computing Platforms. Mol. Biol. Evol. 2018, 35, 1547-1549. [CrossRef]

Publisher's Note: MDPI stays neutral with regard to jurisdictional claims in published maps and institutional affiliations.

(C) 2020 by the authors. Licensee MDPI, Basel, Switzerland. This article is an open access article distributed under the terms and conditions of the Creative Commons Attribution (CC BY) license (http://creativecommons.org/licenses/by/4.0/). 